\title{
NICETA AND AMBROSIASTER. I.
}

NothING so forcibly illustrates the supreme importance, in the history of Christian literature, of the century that intervened between the council of Nicaea and the council of Ephesus, as the number and interest of those who may be called the secondary writers of the period : and the Cambridge University Press has earned itself an honourable distinction by the prominence into which it has helped to recall, within these last few years, more than one half-forgotten commentator or historian. Mr Burkitt led the way in 1894 with his admirable edition of the Rules of the Donatist exegete Tyconius. Dom Butler's Lausiac History of Palladius, commenced in 1898 and completed in 1904, was commended to the readers of the JOURNAL in a notice in the April number (F.T.S. vi $321-355$ ). And the two new publications which the reviewer has now to face, $\mathrm{Mr}$ Souter's Stzdy of Ambrosiaster and Dr Burn's edition of the treatises and collected fragments of Niceta, deal with authors of the same halfcentury as Tyconius and Palladius, and with authors who, like Tyconius and Palladius, deserve to be better known than they have been, and, like them, will largely owe their recognition and reinstatement to the labours of their Cambridge editors.

I.

Dr Burn has already established a secure reputation amongst theological scholars by the excellent work which he has done on the history of the Western Creeds : and regarded as a contribution to a lost chapter of theological literature, his edition of the writings of Niceta ${ }^{1}$ meets a real need and demands the expression of a real gratitude. It is something to have brought together into a single volume a dozen treatises which lie scattered up and down the different tomes of the Latin Patrologia: it is

1 Niceta of Remestana: his Life and Works. By A. E. Eurn, D.D., Trinity College, Cambridge. Cambridge University Press, 1yo 
something too to have found for most of them fresh manuscript authority: it is still more to have vindicated them beyond all reasonable doubt for Niceta of Remesiana against the rival claims of Nicetius, bishop of Trèves in the sixth century, and of Nicetas, bishop of Aquileia in the middle of the fifth. All this Dr Burn has done, and done well; but he would himself be the first to admit that his strength does not lie in the direction of pure scholarship, and it cannot be denied that the text of the present edition is very far from being final.

Beyond even the other writers named above, Niceta may be said to have been re-discovered by the present generation. Antiquity soon lost sight of him: the revival of historical studies at the Renaissance passed him by, and even the industry of the Benedictines of St Maur failed to disinter him from the oblivion of a thousand years. Of his personal history the only channel by which any knowledge has come down to us is his acquaintance with St Paulinus of Nola, who mentions him in one of his letters and addressed to him the seventeenth and part of the twenty-seventh of his Odes. All that we learn of his writings is contained in a few lines of the de Viris Illustribus of Gennadius of Marseilles and a single laudatory reference by Cassiodorus. Niceta's lot was cast in the frontier province of Dacia, early overrun and absorbed by the barbarian invaders, so that the very name of his see-town soon faded out of memory: Remesiana passed, in the hands of scribes, into Romatiana and even into Rome, while his own name was easily corrupted or confused into Nicetas, Nicetus, or Nicetius ${ }^{1}$.

1 The currous form Niceta seems indubitably genuine. Not much stress can perhaps be laid on the evidence of Paulinus because of the exigencies of his metres -he uses both Niceta and Nicetes in the nominative: and the present text of Cassiodorus (when shall we have a critical edition of the de Institutione diuinarum litterarum ?) gives, for the genitive, Niceti. But one at least of the oldest MSS of Gennadius has the nominative Niceta; and the same form is preserved in a Munich ordo catechizandi of the ninth century, and in the Irish laber Hymnorum when attributing to Niceta the authorship of the Te Deum. See Burn, pp. xxxiv, ci, $137,155,156$.

One might perhaps compare the following unstances from the Old Latin bible: 'Acha' for 'A $\chi \dot{a} \zeta$ (Cyprian Testimona ii 9 [codd. A* L*] = Is. vii 10): 'Iona' for Iavâs ( $k$ in Matt. xii 40 : Cypr. Test. 1125 [codd. LX]) : add 'Iuda' the patriarch for Ioúdas in a quasi-citation of Priscillian un Orosius's Commonztorzum \$2, where the only ancient MS reads ' tradidit ... quod esset Ruben in capite Iuda in pectore Leui in corde'.

The modern Slavonic counterpart may be seen in the Montenegrin name Nikita. 
But the same geographical situation which was fatal to his fame in the centuries that succeeded him constitutes part at any rate of his interest and attractiveness to ourselves. If in the second and third centuries Rome was the crucible in which the Greek and Latin elements in Christianity met and fused, we have to look elsewhere for the continuance of the process when the Roman Church had become wholly latinized. Even in southern Italy and Sicily the Greek element was perhaps not prominent until the conquests of Justinian. Conversely, Latin at Constantinople was the tongue rather of statesmen and lawyers than of theologians. It is in fact in the Illyrian and Dacian borderlands that we find, in the period of the great councils, the clearest traces of the inter-penetration of the Greek- and Latin-speaking churches. The basis of civilization in these regions was wholly Roman, and their language was Latin : but their political affinities, from the middle of the fourth century onwards, were so much with the Eastern court and the Eastern empire, that the influence of Greek theology made itself felt there more easily than in most other parts of the West. Niceta himself was definitely a Western churchman: his only travels, so far as we know them, were to Rome, he wrote only in Latin, and it is only Latins who cite him. But the authors whom he uses (and his literary dependence on his predecessors is one of the most interesting features of his writings) are, on the other hand, more often Greek than Latin. Against the clear use of St Cyprian-possibly also of Tertullian and Novatian, less probably of St Hilary-we have to set indubitable points of contact with the Greek Testament, with St Basil, and with St Cyril of Jerusalem, while there are also less certain links with St Irenaeus, St Gregory Thaumaturgus, and St Gregory Nazianzen ${ }^{1}$. And the liturgical employment of

${ }^{1}$ Cyprian ad Donat. $\$ 16=$ de I'salmodiae bono $\$ 13$ (Burn 8r. 3 : 'beatus Cyprianus ') - but why does Dr Burn twice follow the reading of the later of his two MSS against St Cyprian's text ?

de dom. or. $\$ 4=$ de Spintu sancto $\$ 10,12$ (Burn 28.7, 22 : see p. cxlvi [Burkitt]):

de morial. $2_{25}=T e$ Deum lines $7-9$ (Burn pp. cix, 84).

Novatian de Trmitate $=$ de ratione fides $\$$ (Burn $16.15,17$ : see pp. cxlvı, cxlvii [Burkitt]).

${ }_{2}$ Corinthians 13 (Greek) = de Spmintu sancto § $16($ Burn 32. 6).

Cyril Hier. Cat. iv $9=$ de Symbolo $\$ 33,4$ (Burn pp. lxxi, $4 \mathrm{I})$.

Basil Hom i on Fasting $=$ de Vighlus $\delta 9$ (Burn 66. II : 'quidam tur inter pastores eximius'). 
Psalms and Vigils, to the defence of which two of his treatises are devoted, seems clearly to have been an innovation brought to the West from the East.

The literary history of the writings included in Dr Burn's edition illustrates effectively enough the ignorance which enveloped the name and fame of their real author. Not a single one of them is here published for the first time ${ }^{1}$; yet not one has been published before as under the authorship of Niceta of Remesiana. They straggled into print, from time to time, either as claimed by one or other of Niceta's homonyms, the bishops of Trèves and Aquileia, or as waifs in that vast crowd of homeless wanderers which found shelter and protection under the aegis of the name of a Jerome, an Ambrose, or an Augustine. Thus the two tracts de Vigiliis and de Psalmodiae bono were published by d'Achéry in his Spicilegium (vol. 3, ed. i, A.D. I659) as works of Nicetius of Trèves ${ }^{2}$. The de Symbolo appeared at Padua in $1799^{3}$ as a work of Nicetas of Aquileia : and cardinal Mai's editio princeps in 1827 of the three treatises, de diversis appellationibus, de ratione fidei, de Spiritu sancto, made use of the same attribution. The Te Deum was of course generally ascribed to St Ambrose. The name of either St Ambrose or St Jerome is attached in the majority of MSS to the de lapsu virginis, and it was early printed among the works of both those fathers: while in $\mathrm{I} 810$ it was vindicated, together with the de Symbolo, for Nicetas of Aquileia by Peter Braida, canon of Udine, S. Nicetae Episcopi Aquileiensis opuscula duo. Finally, the de ratione paschae was included in Florez's edition (A.D. 1759) of the writings of St Martin of Bracara 4

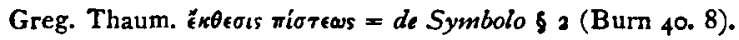

Greg. Naz. Orat $35=$ de ratione fidei $\$ 6$ (Burn $1_{5}$. 25)?

All these references are given by Dr Burn, or by Prof. Burkitt in his exhaustive note 'on the Biblical text used by Niceta', pp. cxliv-cliv : I should like to add St Irenaeus to the list, for I cannot help thinking that a phrase like 'Domınus dives in orationibus [read surely 'operationibus'] nec ullius indigens' (de Vigrlis $\$ 6$ : Burn 62. 20) is an echo of the language of that father.

2 Except, indeed, an alternative Eprstula de lapsu virginis (pp. $13^{1-1} 3^{6}$ ) ; but this there does not seem to be any real reason at all to connect with Niceta : see below, p. 216 .

2 Burn, p. xi, gives the date as 1723 : but that is a comparatively late edition of the Sprolegium.

3 The name of the editor is not given by Dr Burn, p. xi.

- In vol. xv of España Sagrada, appendix 11 p. $4^{13}$. 
Dr Burn, however, has not only gathered together these scattered compositions into a single corpus as the writings of Niceta ; but his own researches, and those of his unwearied adviser Dom Germain Morin, have in many cases enabled him to produce new witnesses to the text, or even new recensions of it. Mai's (Vatican) MS of the de Spiritu was of the fifteenth century: Morin has found one at Cologne of the ninth. A British Museum MS of the eleventh century becomes now the leading witness for the text of the de Symbolo. Of the de Vigiliis the original recension is here printed, from a late Cambridge MS, for the first time, just as of the companion treatise de Psalmodiae bono Dom Morin had printed the original recension some few years before. The case of the de ratione paschae is hardly dissimilar : for a ninthcentury MS at Milan, transcribed by Dom Morin and first published as a continuous text in Dr Burn's edition, presents what seems certainly a more primitive form than that printed by Florez and (independently) by Bruno Krusch ${ }^{1}$.

It would exceed the limits of an article if one were to attempt to do full justice to the internal arguments which support Dr Burn's conclusions in favour of Niceta's authorship of these various treatises. There are of course the general indications of antiquity, such as the knowledge of apocryphal writings like the Inquisitio Abrahae (de psalm. $\S 3$ : Burn 70. II) and the story of Thecla (de laps. virg. $\S \S 10$, I I : Burn II5. 12 and note to 1. 6), or again the acquaintance with Greek fathers stopping short at St Basil and St Gregory. There is the evidence of common style and common expressions: one might instance 'stare in procinctu' found at the beginning of the de Psalmodiae bono and at the end of the de pascha (68. 7: 1 10. 17). But Dom Butler rightly warned us in a recent number of the JOURNAL (vi 595) of the fugitive character of evidence of this sort and of the exaggerated use which a certain class of critics are accustomed to make of it ; and Niceta's works are not devoid of external testimony, scanty indeed, but sufficient for a starting-point.

Under the name of Niceta of Remesiana Gennadius knew, apart from a 'libellus ad lapsam virginem', a set of six 'libelli'

1 Studien zur christlich-mittelalterlichen Chronologze : der 84 jährige Ostercyclus und seme Queilen (Leipzig, 1880), pp. 328-336, under the title 'Tractatus Adthanasi'. Krusch gives the readings of the Milan MS at the foot of the page. 
of instruction for catechumens ('competentes'), of which he has happily preserved the subjects : (i) the moral temper in which baptism should be approached; (ii) the errors of paganism; (iii) faith in the one God, 'de fide unicae maiestatis' ; (iv) against astrology; (v) on the Creed; (vi) on the Paschal Lamb, 'de agni pascalis victima'. In the library of Cassiodorus, the brief and lucid treatise of Nicetas (Nicetus) on the Faith was contained in a single codex with ' the writings of St Ambrose addressed to the emperor Gratian'! An ordo cattchizandi, found in different recensions at Rouen, Munich, and Vienna, contains quotations headed 'Niceta in libro primo ad competentes', ' in libro secundo ad competentes', 'in libro quinto ad competentes'. Among catalogues of ancient libraries, that of Bobbio possessed 'librum instructionis Nicetae episcopi'; in that of Lorsch there was a 'liber Niceti de aequalitate Dei patris et Dei filii, et eiusdem de Spiritu sancto'; in that of Pompuse 'Nicetae episcopi de ratione fidei I, eiusdem de Spiritus sancti potentia lib. I, eiusdem de diuersis appellationibus domino nostro Iesu Christo conuenientibus'. None of the manuscripts thus catalogued appears to be extant; but the Pompuse entry is the missing link which enables us to connect with Niceta three treatises which appear in the same order, under the general title de ratioxe fidei, but without any author's name, in a fifteenth-century MS at the Vatican 2.

In the case of other of the treatises one or more of the extant MSS prefix actually some form of the name Niceta. Thus for the $d e$ Symbolo (book $\mathrm{v}$ of the Instructions ad competentes) the Chigi MS gives 'Explanacio symboli beati Nicete Aquileiensis episcopi habita ad competentes'; the oldest MS of the de Vigiliis and de Psalmodiae bono-Vat. Pal. 2 10, saec. vii-has the titles 'de vigiliis servorum Dei Nicete episcopi ', 'de psalmodiae bono eiusdem Nicetae's; an Irish ascription of the Te Deum to

1 i. e. the five books de Fide and the three de Spiritu sancto.

${ }^{2}$ Vat. lat. 314. That Dr Burn is right in clamıng all three pieces for Niceta I do not doubt: whether the two first of the three-the de ratione fidet and de Spintu sancto-constitute between them, as he thinks, the third book 'de fide unicae maiestatis' of the Instruction to Catechumens is less certain, but at the same time less important

- It is interesting to note that the scribes of later MSS of the same (Gallican) family, to whom the name of the bishop of Trèves was doubtless better known, substitute Nicetius, just as the (Italıan) Chigı MS of the de Symbolo identified our Nicetas with the bishop of Aquilcia. 
Niceta has already been cited, but other MSS, not all of them Irish, offer variants of the same tradition ${ }^{1}$; while the superscription of the de lapsu virginis is in two of the oldest MSS ' epistola Nicetae episcopi', ' epistula Nicaeti episcopi'.

All this historical matter seems to me to have been excellently well unravelled by Dr Burn : it is only when we come to close quarters with the text that the defects of this edition reveal themselves to our notice. In the following paragraphs a summary account will be given of each treatise in turn: with regard to some of them there will be special points to make, but two remarks are called for upon the book as a whole, although naturally they apply most to those parts on which previous editors have done least work. If there is one thing which every editor of an ancient text ought to study with scrupulous care, it is the punctuation. We cannot most of us attain success in the path of emendation; but as much could probably be done for the improvement of texts by right punctuation as by the most brilliant conjectures, and in this matter Dr Burn has left only too much to be done by his successors. A second duty incumbent on the editors of patristic texts is to look out for, and as far as possible trace to their source, the innumerable phrases of scriptural origin which lie scattered up and down the pages of the fathers; and here again the future student of Niceta has been allowed too large an opportunity.

I. The de diuersis appellationibus is a brief tract or sermon upon the titles of our Lord. Dr Burn rightly compares the similar but independent lists in Germinius of Sirmium (c. A.D. 360), in the de Fide Orthodoxa, now attributed to Gregory of Elvira, and in the Damasine decree of A.D. $3^{82}$ : all four fall clearly into place as episodes of the same controversy against Arianism, and even, it would seem, of the same stage in it. For the text, Dr Mercati supplies a collation of a second Vatican MS, four centuries older than that preferred by Mai, which in the main guarantees the correctness of the editio princeps, but adds two new titles, 'Veritas' and 'Vita' (p. 3. 2, 3), omitted in the other MS (and in Mai) by homoeoteleuton. Another certain correction might have been extracted from it in 3. 1 , 'Sacerdos dicitur ... quod per nos dies singulos offerre dignatur' in place of the 1 Burn, pp. c, ci.

VOL. VII. 
' offerri' of the editions, for our Lord could only be called Priest as 'offering', not as 'being offered'. The punctuation of 2. 9-I I might be improved, and the following biblical references should be added: 2. I3, 14, Wisd. viii 1 ; 2. I8, Col. i 16, 17; 2. 19, Is. ix 6 ; 2. 25 , Eph. v 2 ; 3. 3, 2 Tim. i $10 ; 3.6$, Acts iii 16 ; 3. I0, Prov. $x x x$ I9 [xxiv 54]; 3. I3, Jer. ii I $3 ; 3.14$, I 5 , Eph. ii $14-16 ; 4.13$, Matt. xvii $5 ; 4$. 17, Matt. $\vee 6 ; 5.6$, Ps. vii I2, 2 Tim. iv 8 . The tract contains besides two echoes of the Creed, 2. 21 'propter nos homines homo nasci', and 3. 18 'et uiuos iudicaturus et mortuos' - a fresh argument for Niceta's authorship, since we find him elsewhere unusually fond of employing Creed phrases, e. g. de ratione fidei $\$ 3(12.22,26)$ 'de nullis exstantibus factum', 'alterius substantiae', § 4 (I 3. I6) 'unius substantiae'; de Spiritu sancto $\$ 4(23.9)$ ' ex aliqua materia aut ex nihilo factus' 1 .

2. The de ratione fidei and de Spiritu sancto are a couple of sister treatises, directed respectively against Arianism and Macedonianism: and Dr Burn holds that between them they represent the Trinitarian 'librum quem de fide conscripsit' described by Cassiodorus (whose encomium their simple and easy style would amply justify), or in other words the third book of the Instructions. The printed text of both is in the main quite satisfactory: but the following suggestions may be offered. In de rat. fidei $\$ 2$ (Burn 11 . 26) for 'ac si totum confundit cum' restore the 'ac sic totum confundit cum' of Mai, comparing 12. I9 'sic ... quia', 12.21 'sic ... dum'; \$6 (I5. 16) 'esurisse dormisse lacrimasse refertur tunc tristis usque ad mortem '2, read perhaps 'fuisse' for 'tunc'. In de Spiritu $\$ 5$ (24. 24), where one MS has 'in spū potestatis' and the other 'in xps potestate', read 'in Spiritus (sp̄) potestate', comparing 25. 3 'potestas Spiritus'; $\$ 7(25.26)$ for 'an dubium est alieni' (a misprint ?) restore the 'an dubium est alicui' of Mai ; $\$ 14$

1 These allusions stand quite apart from the two express quotations of sections of the (Nicene) creed, pp. 13. 4, 19.3 With regard to the phrase "ex aliqua

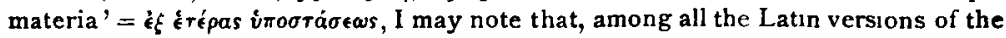
Nicene Creed known to me, 'aliqua' is only found once, in the Creed appended to the Canons of Nicaea by some MSS of the Isidorian version (the Hispana and the codex Veronensis), and 'materia' also only once, in the Creed similarly appended to the Canons in the Gallican version (Ecclestae Ocadentalis Mon. Iur. Ant i 174 ).

2 'Vigilius Tapsensis' de Tnnitate lib. $x$, who borrows (without acknowledgement) a whole page from Niceta, and in part rewrites it, gives 'tristasse usque ad mortem'. 
(30. 18) for 'sicut probatur' of Burn and the earlier MS the sense demands 'sic probatur' with the later MS and Mai ; conversely in the quotation of Acts xiii 2, $\S$ I 5 (31. 13), there seems no reason to retain the unique reading 'et dicit Spiritus sanctus' when the older MS has 'dixit'. Attention might have been called in the notes to two remarkable phrases in the de Spiritu: $\$ 2$ (19.3) 'in Nicaeno tractatu positum est secundum Symboli formam', where Symbolum, 'the Creed 'par excellence, means the A postles' Creed, and 'Nicaenus tractatus' the Nicene ; $\$ 7$ (26. 14) 'per Verbum substantivum', i. e. apparently 'the Personal Word'

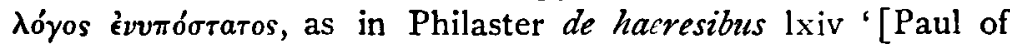
Samosata] qui Verbum dei, id est Christum deum dei filium, substantivum ac personalem et sempiternum esse cum patre denegabat'1.

3. In the de Symbolo we have one of the earliest and most interesting explanations of the Apostles' Creed, at a stage intermediate between its 'Old Roman' and its present form : Niceta appears, for instance, to be the first expositor who includes the clause 'Communionem sanctorum', which he interprets as equivalent to, and explanatory of, communion with the 'Holy' Catholic Church (sanctam, sanctorum). This Creed commentary is excellently represented in Dr Burn's edition: doubtless it lay very near his heart, and one wonders whether it was not the originating cause of the whole undertaking. It has been preserved in so many MSS that questions of text almost reduce themselves to a choice between one or other of them : and here more readings might perhaps have been adopted from Dr. Burn's new authority, the British Museum MS, e.g. 47. 19 mutilabo (nuntiabo the Chigi MS and Mai: mutabo Burn and the rest), 48. I9 Catafriguarum (with the Chigi MS also ${ }^{2}$ ), 50. I I cor-

1 Add biblical references, 1 1. 8, Jo. xiv 27 ; I1. 9, Rom. xi 20 ; I 5. . 7 , Matt. xxvi 38; 16. 2, 3, Luc. viii $25 ; 17.1$, Phil. 116,7 ; 17. I5, Phil ii I1 ; 23. 15, I Pet. ji 10 (Ps. xxxiv [xxxiii] I3); 23. 21 , Jo. xiv. I7; 26. 2, Rom.v 14; 28. 13, I Cor.

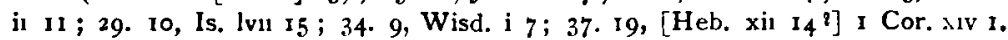
Punctuation : II, 21, substitute with Ma1 interrogation for full stop; I4. I, I 2, 17 . 1,6 , substitute commas for semi-colons; $17.17,24$, substitute commas for full stops ; 17. 27 dele comma; 24. 5, 12, commas for full stops; 33.8 , comma after, not before, 'quiddam'. On page 28 the new chapter should have been marked at 1. 13 , not at 1.8

2 The other family of MSS brings the tract to a premature close at 48 II. 
ruptivum in I Cor. $x v 53^{1}$ (corruptum the Chigi MS, followed by both editors), and, it goes without saying, tamquam in 52. $2^{2}$ : conversely in $4^{8} .9$ 'perhibetur et scriptum est' is a mere scribe's blunder, and ought to have been replaced by 'perhibetur ut scriptum est' of the other family of MSS. Once only is there ground for quarrel with the punctuation of the editor, and that in a sentence where the text is uncertain, 42. 6-8: Dr Burn prints 'si enim falsa incarnatio est, falsa erit et salus hominibus. quod si vera in Christo est, aeque incarnatio est in ipso. utrumque existens : homo quod videbatur, Deus quod non videbatur'; but 'est in ipso' must certainly be taken with what follows, and probably we ought to read either 'quod si vera in Christo, est vira aeque incarnatio, est in ipso utrumque existens' (so in substance Mai), or else 'quod si vera in Christo, in Christo est aeque incarnatio, est in ipso utrumque existens' 3 .

In editing all the pieces so far dealt with Dr Burn had for his precursor cardinal Mai's SS. Episcoporum Nicetae et Paulini scripta e Vaticanis codicibus edita (Rome A. D. 1827). For all but one of them he has been able to use fresh authorities: and the net gain towards the restoration of the ipsissima verba of Niceta is very considerable. But Dr Burn's services are more considerable still in the two interesting tracts of which we have now to speak: though as less has been done on them hitherto, much remains over to do even after the present edition.

4. The two sister discourses de Vigiliis and de Psalmodiae bono are addressed to the defence of a liturgical innovation, the introduction of night services with psalm-singing-'psalmi', 'orationes', 'interpositae lectiones', 79. 6-on Saturdays and Sundays. All the parallel pieces of evidence, in the history of the church of Antioch, in the writings of St Basil, St Augustine, and John Cassian, combine to establish the last quarter of the fourth century as their probable date, and therewith serve to

1 'Corruptivum' is the reading of Tertullian and Cyprian.

2 It is hard indeed to say why Dr Burn, against the older MS and the example of Mal, introduces a monstrosity like tanquam into his text. He withdraws the form explicitly in his comgenda in two other instances, 47.12 and 80.12.

3 Of biblical references add 44. 16, 17, Acts ii $24 ; 44.17,18$, Wisd. xvi $13 ; 45$. 8, 9, Matt. xxv 46; 45. I1, Jo. xv $26 ; 46.13$, Eph. $114 ; 46$, 14, Jo. xvi 13; 47. 13, Matt. xviii $17 ; 48.7,8$, Eph. 1 13, Iv 4, $5 ; 50.19$, 20, Marc. vui 38 ; 51 . I1, Luc. $x \times 36 ; 5$ 1. 14, Jo. xvii $3 ; 51,23,2$ Tim. 1114 1 ; 52.16 , Eph. 113. 
support the claim of Niceta as their probable author. Both discourses are preserved together under the name Niceta (or Nicetius ${ }^{1}$ ) in a group of French and Rhenish MSS ranging from the seventh century to the twelfth: each is also preserved separately in a longer recension and in later MSS under the name of Jerome. Yet not the least doubt can exist that the Jerome recension is the original, and that the other has been simply but skilfully formed out of it by omitting all that seemed personal, or superfluous, or (in the eyes of a later generation) of questionable value: Dom Morin suggests, and the suggestion seems a probable one, that this later text owes its origin to Caesarius of Arles at the beginning of the sixth century. The fuller form, which Dr Burn is the first to print, is so replete with interest that his readers will gladly accord him all the indulgence due to an editio princeps: but it cannot be denied that the crop of 'corrigenda' is considerable. The following scriptural references are left unnoticed: 58 . I, Ps. vi $6(7) ; 6$ I. 19, 20, Luc. ii 36, 37; 64. I I, 2 Cor. xi $27 ; 65.2$, Eph. vi I 7 ; 66. 4, 1 Cor. xiv I5; 63. 4, Eph. v 8, I Th. v 5; 74. 9, Ps. civ (ciii) $30 ; 75.10$, Ps. 1 (xlix) 14; 77. 12, Matt. xxvi 30 (Marc. xiv 26); 79. 15, 16, I Cor. xiv 15;80.11, Gal. i 10;81. 12, Ps. cl 5; 82. 18, Ps. lxxxiv (lxxxiii) 5. The punctuation should be altered in the following places: 6r. 5, substitute comma for the full stop which separates ut from its subjunctive; 64. 21, comma for semi-colon; 65. 16, 17, add comma after inania, and substitute comma for semi-colon after dedit; 69. 2, add comma after proferam; 71. 1, 73. 3, substitute commas for the full stops which separate the subordinate from the principal clause; 72. 15 , add comma after contribuit; 75.6 , introduce sense by transferring the comma from consczentia to fundebatur (comparing 75. 12, 77. I) ; 75. 20, colon for full stop; 78. I I, rescue Niceta from the imputation of a false concord ('ministerium ... ingentem') by putting the comma not after ingentem, but before it, 'ingentem magnam', i. e. 'vastly great ': ; 80. 22, dele comma after sonum; 81. 20, add comma after cele-

1 Compare what was said above, p. 208 n. 3, on the appearance of this name in Gallican MSS.

3 As however I have not succeeded in finding any evidence for an idiom of this sort, it would probably be better to remove 'magnam' from the text altogether as a gloss on 'ingentem', which to some copyist or reader may easily have seemed too vulgar an epithet to stand in the text. 
bratur; 82.2 , the words 'et quotiens volueris orare privatim ' go with what precedes, not with what follows, so that the comma before it must be removed and a colon inserted after privatim.

The text of these two treatises has not been so well preserved as that of the libelli Instructionis, and a wider field seemed to lie open for conjectural emendation. But, as a matter of fact, the only two suggestions I have to offer on the first half of the de Vigiliis are based on Dr Burn's apparatus of variants: in 57. 3 'nostri essent quia sumus utique christiani', read quod for quia with the 'Niceta' family, and punctuate 'nostri essent quod sumus, utique christiani', ' they would belong to us and be what we are, that is of course Christians': and in 60. 10 'ne vespertinas tantum horas noctis aestimes appellatas', read noctes with three MSS for noctis-Niceta is taking up the 'in noctibus' of Ps. cxxxiv (cxxxiii) 2 quoted immediately before. For the second half of the de Vigiliis and for the whole of the de Psalm. bono, such collectanea as I had put together are superseded for the moment by the fortunate discovery in the Vatican library of a new and valuable authority for the text. Dr Mercati hopes to transcribe this MS for publication in an early number of the JOURNAL: and it would be premature to criticize a text for which the apparatus is incomplete. As a specimen, however, of the assistance that may be expected from it, I will print the opening sentences of the de Psalm. as they stand in Dr Burn's edition and in the new Vatican MS respectively ${ }^{1}$.

Burn, pp. $67,68$.

Qui promissum reddit debitum soluit. memini me pollicitum, cum de gratia et utilitate uigiliarum dixissem, sequentı sermone in hymnorum laude et mysterio esse dicturum, quod nunc hic sermo Deo donante praestabit. nec sane potest tempus aliud aliter inueniri quam istud. a filiis lucis nox praeuidere dicitur, quo silentium et quies ab ipsa nocte praestatur, cum hoc ipsud celebratur
MS Vat.

Qui promissum reddit debitum soluit. memini me pollicitum, cum de gratia et utilitate uigiliarum dixissem, sequenti sermone hymnorum et laudum ministerio esse dicturum: quod nunc hic sermo Deo donante praestabit. nec sane potest tempus aliud aptius inueniri, quam quo filiis lucis nox pro die ducitur, quo silentium et quies ab ipsa nocte praestatur, quo hoc ipsud celebratur quod

1 It must be understood that this passage was not chosen as an average specimen of Dr Burn's text, but rather as what appeared to be the most corrupt part of it. 
quod cupit sermo narrare. apta cupit sermo narrare. apta est est adoratio muliti quando stat in adortatio militi quando stat in proprocinctu. sola nautis conuenit cinctu sollicitus : nautis conpetit cantilena cum remis incumbunt, cantılena cum remis incumbunt mare uerrentibus aptıssima est. mare uerrentibus : aptıssima est et nunc huic conuentul ad hymno- et nunc huic conuentui ad hymnorum mysterium congregato ipsius rum ministerium congregato ipsius operis sicut praediximus adloquar. operis sicut praediximus adlocutio.

In puzzling over Dr Burn's text three things had become clear: (i) that mysterio, mysterium, ought to be corrected, by comparison with $77.11,78.6,1 \mathrm{I}$, into ministerio, ministerium; (ii) that adoratio militi could not stand, but must be altered into either adiuratio or adhortatio; (iii) that mare verrentibus went with remis, and aptissima est with what followed. All this-but how much more than this!-is given us by the new text.

5. Of the Te Deum I have neither the knowledge nor the space to speak in detail. But we remember that the de Psalmodiae bono is a defence of the introduction of a special service of singing into Church worship : we find that Paulinus of Nola emphasizes hymn-writing as the conspicuous merit of his friend Niceta : we know that tradition points to the end of the fourth century as the date of composition of this greatest hymn of the Western Church: and we are then confronted with MSS which actually prefix to the Te Deum the name of Niceta or Nicetus. So indefinitely numerous are the writings attributed to the great Latin Fathers, that experience teaches us that the title 'Ambrose', 'Augustine', or 'Jerome ' constitutes of itself hardly even a presumption of authenticity: but the case is different with an unknown writer and an unfamiliar name, and it may be anticipated that the ascription of the Te Deum to Niceta, brought into new prominence by the efforts of Dom Morin and Dr Burn, will gradually win its way to universal acceptance.

6. Nor need we delay over the de pascha. It is beyond question an interesting and primitive treatise, well worth the attention which $\mathrm{Dr}$ Burn has given it: its claim, however, to rank among the works of Niceta is conjectural, and the arguments which support the claim are subjective, so that it was rightly classed among the opera dubia. But it would be a highly useful task for some younger scholar of chronological tastes to amal- 
gamate in a single volume all the more ancient pieces, Greek and Latin, which deal with paschal computations and paschal controversies: they cannot be studied profitably in isolation, and the collection in Bruno Krusch's Studien zur christlich-mittelalterlichen Chronologie, invaluable for its particular subject ('the 84 year Easter-cycle and its sources'), lacks most of the Greek and the earliest Latin material.

7. That a tract ad lapsam virginem was among the works of Niceta we knew on the testimony of Gennadius : and more than one of the older critics had already identified it with an epistle 'de lapsu Susannae devotae et cuiusdam lectoris', which is found now under the name of Ambrose, now under that of Jerome, but also in a small group of MSS-including, however, the oldest of all-under that of Nicaetus or Niceta. I do not really know why Dr Burn did not rank it among the undoubted works of our author: and I am sure that Dom Morin shewed less than his customary acumen when he brought forward, as an alternative candidate for the place, an unpublished letter from the great Corbie MS of Canons (Paris, lat. I2097: saec. vi). Dr Burn accords to this latter document-though some words in the preface suggest that he did not do so without misgivings-an equal position with the other claimant among the opera dubia: but one could not easily believe that 'persona regalis' (133.9), which Morin interprets of Theodosius I, means anything but a Frankish king ${ }^{1}$.

The treatise which I take leave to regard as the genuine Niceta offers in its history and transcription a curious parallel to the de Vigiliis and de Psalmodiae bono. In either case a shorter recension is extant under the name of Niceta, a longer under the name of some better known father, Jerome or Ambrose ${ }^{2}$ : but in either case the longer recension, in spite of its falsified title, is undoubtedly the original. In the case of the tracts on Vigils and Psalm-singing, Dr Burn rightly printed the longer recension

1 For 'in eo uoto uestroque commodo' (133. 4 : a misprint?) read 'meo uoto uestroque commodo'.

In the April number of the Journal (vi 433) Mr Souter published a list of twelve MSS giving the authorship of St Ambrose, and fifteen that of St Jerome. None are older than the ninth century, while the Murbach MS of the 'Niceta' recension (now no. 68 in the library at Epinal) is at any rate earlier than the middle of the eighth. 
in the text: it is unfortunate that he should have adopted the converse arrangement in the de lapsu, for time after time one has to look to the apparatus at the foot of the page (where Dr Burn repeats the longer recension from the editions of St Ambrose) for a clause or a paragraph necessary to complete the sense. Of course there are numerous details in which Dr Burn's MSS, being doubtless older than any of the fuller recension hitherto employed, enable us to correct the printed text ${ }^{1}$ : but I do not think there is a single instance where any substantial addition of the longer recension can be shewn to be alien to the true form of the text. And the editor practically throws up his case when he prints the last three pages of the treatise, which are altogether absent from his MSS, continuously with the rest of the text ${ }^{2}$.

The real interest of the shorter recension, apart from its preservation of the author's name, lies in the remarkable colophon with which the truncated text concludes: 'Hanc epistolam sanctus emendauit Ambrosius quia ut ab ipso auctore fuerat edita non erat ita, quoniam ab imperitissimis fuerat uiciata. Emendaui Mediolano.' Now it seems as impossible to refuse all credence to this note as it is to accept it as it stands. On the one hand, St Ambrose was an elder contemporary and a not very distant neighbour of Niceta-the fixed points in the latter's life range from 398 to 414 , while Ambrose died in 397-and if he had wanted a corrected copy of Niceta's writings would naturally have applied to him in person. On the other hand, the formula 'Emendaui Mediolano' (Mediolani?) has all the ring of genuineness : compare the 'Emendavit Iustinus Romae' found in one family of the MSS of Epp. 28 and 37 of St Cyprian, or the still more famous subscription of the ex-prefect Nicomachus, early in the fifth century, to the second pentad of Livy, "Nicomachus Flavianus v. c. III praef. urbis emendavi apud Hennam.' I would suggest the following solution of the difficulty. Some time in the fifth century a scholar of the name of Ambrose edited at Milan this treatise of Niceta, and appended to his edition the customary record of his work, 'Ambrosius emendavi

1 Thus in 116. 12 read with them ut quid for et quid, and in 123.3 haec for hae.

2 I am so sure that no one who reads the text and apparatus carefully together will question this conclusion, that I do not burden the pages of the Journal with unnecessary proofs. 
Mediolani.' A later scribe or editor, supposing that no Milanese Ambrose could be other than the Saint, and puzzled to know why St Ambrose should be 'emending' Niceta, offered the explanation contained in the extant colophon. If this be so, no credit whatever need be attached to anything beyond the name of 'Ambrose', the locality of 'Milan', and the fact of 'emendation'.

The biblical references are more than usually incomplete in this tract: add 1I2. I1, Eph. ii I7; II3. 8, Jer. xxx 15?; II2. 14, I Cor. xiii 6; I12. 15, Prov. vii 24; 113. 24, Eph. ii 22; I 14. 18, Wisd. i 5 ; I16. 12, Ps. xiv (xiii) 5 ; 117.13 , Rom. xii 1 , I John ii $2 ; 118.15$, cf. I Tim. vi $12 ; 118,20,2$ Cor. iii $3 ; 121.7$, Rom. vi 21 ; I21. I2, Ps. xlv (xliv) I1; I22. 12, Lam. ii I6; 122. I8, Rom. ii 24 ; 123. 4, Luc. v 32 ; 123. 12, A poc. iii 5, cf. Ps. lxix (lxviii) 29; 124. 11, Ps. xxii (xxi) I4 [15]; 125. 6, I Cor. iv 3 ; 126. 2, Rom. xv 16; 126. 4 (compare too 129. 7), Matt. xxvi 24, Mc. xiv 21 ; 127.8, Tobit iv 9; I28. 2, Matt. xxii 13, \&c. ; 129. 1, 2, Lam. i 21 ; 129. 6, 7, Jer. xx 14; 129. 17, 18, Is. xlviii 22 ; I29. 23, 24, cf. Ps. cvii (cvi) 42 ; 129. 29, Ps. vi 5 [6] ; 130. ro-12, Jonah ii 5 ; 130. 18, 19, Ps. cxlvi (cxlv) 7, 8; 131. 6, 7, Prov. v 22. Even where the references are marked at the foot of the page, the words quoted are not infrequently left in roman type-on what principle $I$ have been unable to discover. On the other hand the punctuation is not often amiss : yet in $114.21,118.2,4,125.17$, substitute commas for semi-colons, and similarly in the apparatus criticus p. $12 \mathrm{I}$, seventh line, comma for full stop before 'ille qui non mentitur', and p. 125 , third and ninth lines, commas for semi-colons.

But if the present edition can hardly be called, from a textual point of view, final, it is for all that unlikely that the future will produce any editor of Niceta whose services would outweigh those of Dr Burn. The best is too often the enemy of the good: and though a more finished piece of work might have been produced if the five years, which we are told in the preface were spent over this edition, had been doubled, I do not think that anyone will regret that that course was not taken. How much patristic literature is there of which we should be only too thankful to possess as compact and serviceable a presentation as Dr Burn has given us of the writings of Niceta! Gratitude to 
him is our last, as it was also our first, feeling : criticism, so far as it is necessary, may be sandwiched in between. And the reviewer may be permitted in conclusion to express the earnest hope that Dr Burn, even in the midst of new and engrossing pastoral duties, will find the time and the courage to deal with yet others of the neglected fragments of Christian antiquity.

C. H. TURNER. 